\title{
Development and Validation of High-Performance Liquid Chromatography Method for Analysis of Efavirenz In Capsule Dosage Form
}

\author{
Punam S. Desai*, Archana R. Dhole, Rajeshwar V. Chavan \\ Rajarambapu College of Pharmacy, Kasegaon, Tal. Palus, Dist. Sangli, Maharashtra, India
}

\begin{abstract}
The present research work is to develop accurate and precise UV and HPLC method development for analysis Efavirenz in their capsule dosage forms and its validation. UV method for Efavirenz in their capsule dosage forms was developed by using the spectrum mode of analysis of SHIMADZU 1800UV /Visible spectrophotometer. Method was developed by using methanol as a solvent. By scanning, the each solution was in the range of 200-450 nm. $245 \mathrm{~nm}$ was selected as a wavelength for Efavirenz Capsule method was validated with the help of parameter as linearity, range, accuracy, precision (intraday and interday),LOD LOQ Ruggedness, Robustness. HPLC method for analysis of Efavirenz in their capsule dosage forms was developed by using HPLC system of JASCO UV -2075 with ,Column Intersil ODS-3V ( 250 x 4.6mm) columns chromatogram for was developed using mobile phase methanol :Isopropanol in the ratio of 80:20 v/v. Retention time was achieved with $3.35 \mathrm{~min}$,flow rate $0.5 \mathrm{ml} / \mathrm{min}$,wavelength $245 \mathrm{~nm}$ respectively. Method was validated with the help of parameter as linearity, range, accuracy, precision (intraday and interday), LOD, LOQ, robustness.
\end{abstract}

Keywords : High Performance Liquid Chromatography, Ultra-Violet, LOD, LOQ Efavirenz, Validation.

\section{INTRODUCTION}

Antiviral and antiretroviral are a class of medications explicitly utilized used like viral and retroviral ailments prompted by infections, for example, HIV, herpes microbes, hepatitis B and C. Antiviral is a class of medications used to treat contaminations with infections. Antiretroviral is a medication used to battle disease with retrovirus, including HIV. Several other classes of antiretroviral work at numerous periods Life of HIV cycle. Viruses are modest (more often than not somewhere in the range of 20 and 30 $\mathrm{nm}$ ) and necessary intracellular parasites comprise of either twofold or single stranded DNA or RNA in a protein coat called capsid. There are two sorts of antiviral operators, non-retroviral and retroviral.
Non-retroviral inhibitors follow up on ailments with non human immunodeficiency infection (HIV) [1]. Antiretroviral specialists, notwithstanding, smother HIV replication, postpone AIDS inception and delay the survival of patients [2]. The field of antiviral research has taken on another measurement since the worldwide spread of human immunodeficiency infection (HIV) caused the (AIDS) pestilence during the 1980s, with exceptional endeavors in scholastic and pharmaceutical labs to grow new successful antiviral treatments [3], [4].This paper describes the development and validation of a UV and HPLC method for determination of Efavirenz in their capsule dosage form.. Analytical chemistry is defined as the art and science of determining the composition of material in terms of elements of compound 
contained in them. in a modern industrialized society the analytical chemist has very important role to perform [5]. Spectroscopy is the branch of science that is related with the study of interaction of electromagnetic radiation with matter. This is the most powerful tool available for the study of atomic and atomic structures and used in the analysis of wide range of samples [6], [7]. It is one mode of chromatography, one of the most used analytical techniques. Chromatographic process can be called as 'separation technique involving mass transfer between stationary phase and mobile phase. HPLC utilizes a liquid mobile phase to separate the components of mixtures. It is one mode of chromatography, one of the most used analytical techniques. Chromatographic process can be called as 'separation technique involving mass transfer between stationary phase and mobile phase. HPLC utilizes a liquid mobile phase to separate the components of mixtures [8].The method validation is validating the method that has adopted for the analysis. The analytical procedure shows a way to analyze analytical method validation is required for herbal, new process and reaction, new elements (new chemical entities), active constituents, residue, impurity profiling and interest factors in different metrics. Analytical method involves techniques, method, process and protocols [9].

\section{METHODS AND MATERIAL}

\section{A) Drug Acquisition}

Table 1. Medication test obtainment and producers

\begin{tabular}{|c|c|c|}
\hline Sr. No. & Names of Drugs & Drug procurement \& Manufacturers \\
\hline 1 & Efavirenz & Cipla Ltd., Goa. \\
\hline $\mathbf{2}$ & Efavirenz Capsule & Shree Chaitnya Medico, Karad. \\
\hline
\end{tabular}

B) Reagents and Chemicals used

Table 2. Reagents and chemicals used

\begin{tabular}{|c|c|c|}
\hline Sr. No. & Name of Chemicals/Reagents & Suppliers \\
\hline 1 & Methanol (HPLC grade) & Shree Samarth Traders, Islampur \\
\hline 2 & Acetonitrile (HPLC grade) & Shree Samarth Traders, Islampur \\
\hline 3 & Isopropanol (HPLC grade) & Shree Samarth Traders, Islampur \\
\hline 4 & Doubled distilled water & $\ldots . .$. \\
\hline
\end{tabular}


C) Instrument Used

Table 3. Instrument used

\begin{tabular}{|c|c|c|}
\hline Name of Instruments & Model-Serial No. & Manufacturer \\
\hline UV spectrophotometer.(double beam) & A 114545, 00377 & Shimadzu Corporation, Japan. \\
\hline Jasco 2075 plus HPLC System & JASCO 2075 plus & JASCO, Japan. \\
\hline Ultrasonicator & ------ & Rami Instruments Pvt. Ltd \\
\hline Singe Pan Electronic Balance & ------ & Elder Instruments Pvt. Ltd \\
\hline
\end{tabular}

\section{DRUG PROFILE: EFAVIRENZ}

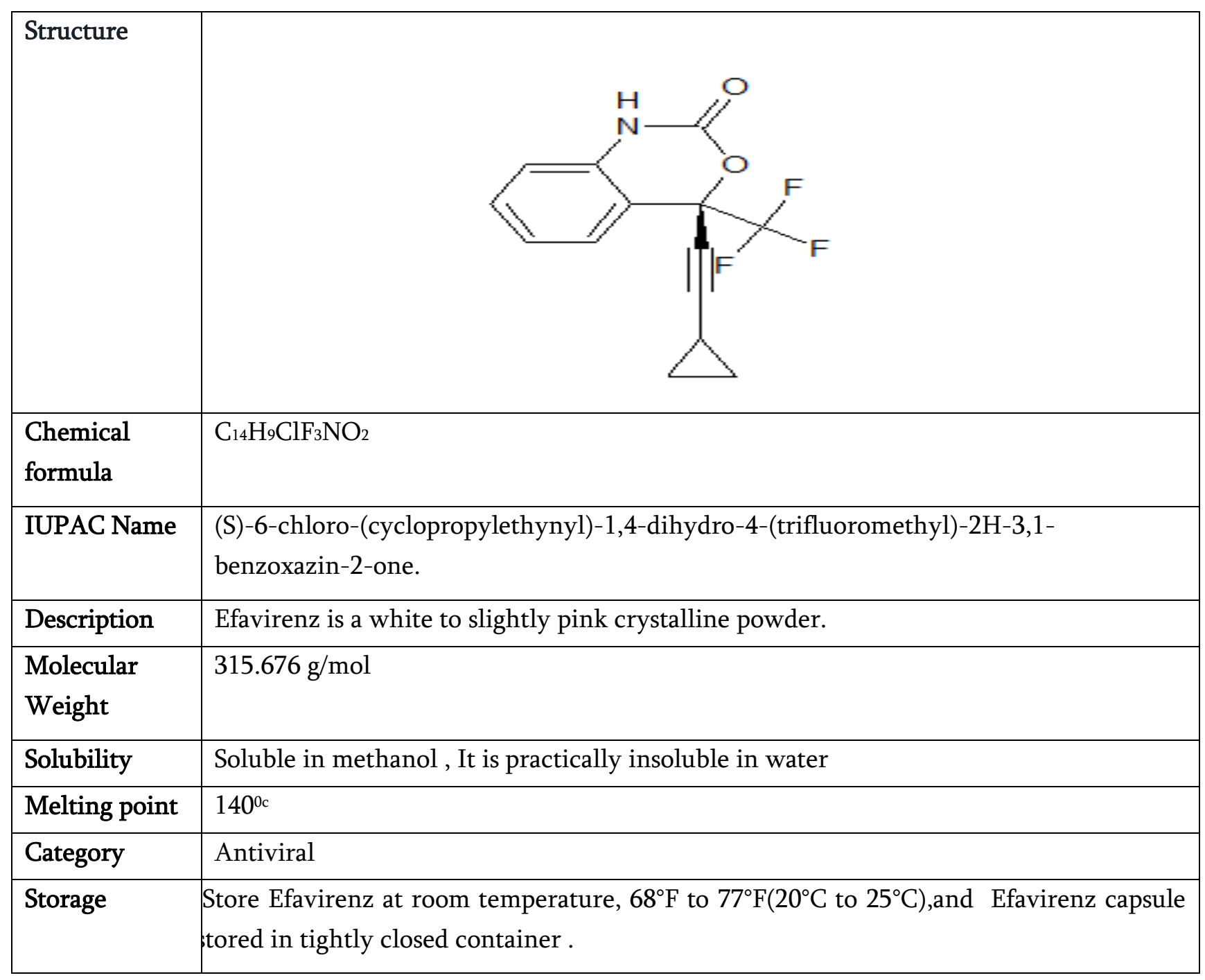




\section{EXPERIMENTAL WORK-}

\subsection{Drug characterization}

A. Organoleptic characteristics- Colour, Odour, Test were determined.

\subsection{Physical parameters}

\section{B. Melting point}

Melting point of Efavirenz capsule drug were determined by taking a small amount of pure drug in a capillary tube closed at one end and placing it in melting point apparatus. The temperature at which the drug melts was noted. Average of triplicate reading was taken, and compared with literature.

\section{Solubility studies}

Efavirenz capsule samples were taken in amount of pinch and added to the test tubes containing different solvents. For this purpose various solvent like water methanol, Sodium hydroxide, Isopropanol and ethanol were used.

\section{IR studies}

The drugs received from the company were checked by carrying out IR studies.IR spectra of Efavirenz capsule were recorded on FTIR 410, Jasco, Japan.

\subsection{UV analysis [10], [11]}

It is must to observe pattern of UV absorbance with prior to HPLC method development for drug.

\subsection{Selection of common solvents}

Solubility studies were carried out with a view to find a suitable solvent in which the EFA Capsule are completely soluble and stable. Solvents like ethanol, methanol, Sodium Hydroxide, Isopropanol were tried for checking solubility of EFA capsule after assessing the solubility of drug in different solvent methanol has been selected and finalized as common solvent to observe spectral characteristics.

\section{Determination of $\lambda \max$}

$100 \mathrm{mg}$ of Efavirenz capsule drug was dissolved in $100 \mathrm{ml}$ of solvent methanol. Thus $1000 \mu \mathrm{g} / \mathrm{ml}$ stock solution was prepared. In that $10 \mathrm{ml}$ of stock solution was taken and suitably diluted with $100 \mathrm{ml}$ of methanol solvent .Thus $100 \mu \mathrm{g} / \mathrm{ml}$ (solution 1) was formed. From this solution 1, $10 \mathrm{ml}$ of solution was pipette out and dilute up to $100 \mathrm{ml}$ and the concentration of this solution was $10 \mu \mathrm{g} / \mathrm{ml}$ of Efavirenz capsule was prepared by appropriate dilution of standard stock solution then solution was filtered and its UV spectrum was recorded in the wavelength range 450-200 $\mathrm{nm}$.

Preparation of standard stock solution and study of Beer-Lamberts law ${ }^{[12]}$

\section{Standard Efavirenz capsule stock solution}

Accurately about $10 \mathrm{mg}$ EFA capsule was weighted and transferred in $100 \mathrm{ml}$ volumetric flask. To it 50 $\mathrm{ml}$ of methanol was added to dissolve the drug completely with vigorous shaking. Then the volume was made up with the same solvent up to the mark to give the drug stock solution of concentration. $100 \mu \mathrm{g} / \mathrm{ml}$ and to take appropriate dilution and make up the volume with using methanol.

\section{Study of Beer-Lambert's law}

Working stock solution of EFA capsule was prepared with methanol to get concentration range of 2$10 \mu \mathrm{g} / \mathrm{mL}$ the absorbance of resulting solutions was measured at their respective wavelength. A calibration curve was constructed to study the BeerLambert's Law and regression equation. Dilution used for calibration curve as below,

EFA capsule $10 \mathrm{mg}$------------ stock solution of 100 $\mathrm{mL}$ (concentration $100 \mu \mathrm{g} / \mathrm{mL}$ )

1] $0.2 \mathrm{~mL}$ from stock solution --------- $10 \mathrm{~mL}(2 \mu \mathrm{g} / \mathrm{ml})$

2] $0.4 \mathrm{~mL}$ from stock solution --------- $10 \mathrm{~mL}$ $(4 \mu \mathrm{g} / \mathrm{ml})$ 
3] $0.6 \mathrm{~mL}$ from stock solution $10 \mathrm{~mL}$ $(6 \mu \mathrm{g} / \mathrm{ml})$

4] $0.8 \mathrm{~mL}$ from stock solution $10 \mathrm{~mL}$ $(8 \mu \mathrm{g} / \mathrm{ml})$

5] $1 \mathrm{~mL}$ from stock solution $10 \mathrm{~mL}$ $(10 \mu \mathrm{g} / \mathrm{ml})$

\subsection{UV spectroscopy}

\subsubsection{Method validation ${ }^{[13]}$}

The method was developed and validated according to analytical procedure as per the ICH guidelines for validation of analytical procedures in order to determine linearity, Precision, and accuracy LOD, LOQ Ruggedness, Robustness for the analyte.

\section{A) Linearity}

Linearity was studied by preparing serial dilutions using standard stock solution in $10 \mathrm{ml}$ volumetric flask. I.C.H. recommends that for the establishment of linearity, a minimum of 5 concentrations normally used. The various dilutions used for linearity study are as follows. And the further study was carried out. The absorbances were measured at $245 \mathrm{~nm}$. The linearity of the relationship between absorbance's and concentration was determined by plotting the calibration curve for Efavirenz capsule.

$10 \mathrm{mg}$ Efavirenz capsule stock solution of $100 \mathrm{~mL}$ (concentration $100 \mu \mathrm{g} / \mathrm{mL}$ )

1] $0.2 \mathrm{~mL}$ from stock solution $10 \mathrm{~mL}$ $(2 \mu \mathrm{g} / \mathrm{mL})$

2] $0.4 \mathrm{~mL}$ from stock solution $10 \mathrm{~mL}$ $(4 \mu \mathrm{g} / \mathrm{mL})$

3] $0.6 \mathrm{~mL}$ from stock solution $10 \mathrm{~mL}$ $(6 \mu \mathrm{g} / \mathrm{mL})$

4] $0.8 \mathrm{~mL}$ from stock solution $10 \mathrm{~mL}$ $(8 \mu \mathrm{g} / \mathrm{mL})$

5] $1.0 \mathrm{~mL}$ from stock solution $-10 \mathrm{~mL}$
B) LOD and LOQ

Limit of quantification (LOQ) is that the lowest quantities of associate degree analyte in a very sample that may be quantitatively determined with appropriate preciseness and accuracy.

$\mathrm{LOD}=3.3 \mathrm{X} \sigma / \mathrm{s}$

$\mathrm{LOQ}=10 \mathrm{X \sigma} / \mathrm{s}$

Where,

$\sigma=$ Standard deviation

$\mathrm{S}=$ Slope of calibration curve

\section{C) Accuracy}

Accuracy of an analytical method is the closeness of test results obtained by the method to the true value. To check the accuracy of the proposed method ,accuracy were carried out $80,100,120 \%$ of test conc. as per ICH guidelines .Known amount of standard drugs were added to analyzed sample and subjected to the developed UV method. Then the absorbance was taken and further calculation was carried out. The Accuracy study was performed three times at each level.

\section{For $80 \%$ concentration accuracy}

To perform for $80 \%$ of conc.

To taken $10 \mathrm{mg}$ Efavirenz capsule sample to it add 8 mg of standard Efavirenz it mix properly.

From this pool, weight accurately $10 \mathrm{mg}$ of mixture sample and transferred in $100 \mathrm{ml}$ vol.flask to it $50 \mathrm{ml}$ methanol was added.

\section{Kept for ultrasonication}

Final volume was made upto the mark with methanol.

Above solution was filtered through whatmann filter paper. 
Take absorbance

\section{For $100 \%$ concentration accuracy}

To perform for $100 \%$ of conc.

\section{$\downarrow$}

To taken $10 \mathrm{mg}$ Efavirenz capsule sample to it add 10 mg of standard Efavirenz it mix properly.

From this pool, weight accurately $10 \mathrm{mg}$ of mixture sample and transferred in $100 \mathrm{ml}$ vol.flask to it $50 \mathrm{ml}$ methanol was added.

\section{Kept for ultrasonication}

Final volume was makeup with methanol at the mark.

Above solution was filtered through whatmann filter paper.

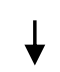

Take absorbance

\section{For $120 \%$ concentration accuracy}

To perform for $120 \%$ of conc.

To taken 10 mg Efavirenz capsule sample to it add 12 mg of standard Efavirenz it mix properly.

From this pool, weight accurately $10 \mathrm{mg}$ of mixture sample and transferred in $100 \mathrm{ml}$ vol.flask to it $50 \mathrm{ml}$ methanol was added.

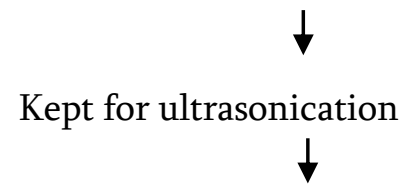

Final volume was makeup with the methanol at the mark.

Above solution was filtered through whatmann filter paper.

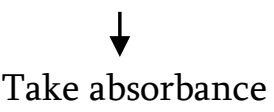

\section{D) Precision}

Precision of an analytical methodology is that the degree of agreement among individual results once the strategy is applied repeatedly to multiple readings of a homogeneous sample. It is expressed as \%R.S.D. and S.D. of series of measurements. The interday's and intra precision was determined using $10 \mu \mathrm{g} / \mathrm{mL}$ concentration of Efavirenz capsule.

1] $0.2 \mathrm{~mL}$ from stock solution $10 \mathrm{~mL}$ $(2 \mu \mathrm{g} / \mathrm{mL})$

2] $0.4 \mathrm{~mL}$ from stock solution $10 \mathrm{~mL}$ $(4 \mu \mathrm{g} / \mathrm{mL})$

3] $0.6 \mathrm{~mL}$ from stock solution $10 \mathrm{~mL}$ $(6 \mu \mathrm{g} / \mathrm{mL})$

4] $0.8 \mathrm{~mL}$ from stock solution $10 \mathrm{~mL}$ $(8 \mu \mathrm{g} / \mathrm{mL})$

5] $1.0 \mathrm{~mL}$ from stock solution $10 \mathrm{~mL}$ $(10 \mu \mathrm{g} / \mathrm{mL})$

\section{A) Intraday}

It was carried out by estimating the corresponding absorbance three times on the same day between three hrs interval, measurement of absorbance was expressed in terms of \% Relative Standard Deviation (\%RSD).The given dilution was used and the absorbance was taken by different intervals in the same day like 10am, 1pm, $4 \mathrm{pm}$ and further calculation was done.

\section{B) Interday (different days)}

It was carried out by estimating the corresponding absorbance of same sample was recorded on three different days, measurement of absorbance was expressed in terms of \% Relative Standard Deviation (\%RSD). The given dilution was used and the absorbance was taken by different intervals in a different day like first day, second day, third day and further calculation was done.

\section{E) Robustness}

The strength of analytical methodology may be a live of its capability to stay unaffected by tiny however 
deliberate variations in methodology parameters and provides a sign of its dependability throughout traditional usage. By using this dilution the absorbance was taken by changing the concentration then the further calculation was carried out.

1] $1.0 \mathrm{~mL}$ from stock solution $10 \mathrm{~mL}$

$(10 \mu \mathrm{g} / \mathrm{mL})$

2] $1.2 \mathrm{~mL}$ from stock solution $10 \mathrm{~mL}$

$(12 \mu \mathrm{g} / \mathrm{mL})$ $10 \mathrm{~mL}$

3] $1.4 \mathrm{~mL}$ from stock solution $(14 \mu \mathrm{g} / \mathrm{mL})$

4] $1.6 \mathrm{~mL}$ from stock solution $10 \mathrm{~mL}$ $(16 \mu \mathrm{g} / \mathrm{mL})$

\section{F) Ruggedness}

The strength of an analytical methodology is that the degree of dependability of takes a look at results obtained by the analysis of similar samples beneath a spread of conditions, like totally different laboratories, different laboratories, different analysts, different instruments, different lots of reagents, different days, etc. By using this dilution the absorbance was taken and the further calculation was carried out.

1] $0.2 \mathrm{~mL}$ from stock solution $10 \mathrm{~mL}$ $(2 \mu \mathrm{g} / \mathrm{mL})$

2] $0.4 \mathrm{~mL}$ from stock solution $10 \mathrm{~mL}$ $(4 \mu \mathrm{g} / \mathrm{mL})$

3] $0.6 \mathrm{~mL}$ from stock solution $10 \mathrm{~mL}$ $(6 \mu \mathrm{g} / \mathrm{mL})$

4] $0.8 \mathrm{~mL}$ from stock solution $10 \mathrm{~mL}$ $(8 \mu \mathrm{g} / \mathrm{mL})$

\subsection{HPLC method development}

It carried out by following points

\subsubsection{Selection of analytical wavelength}

The wavelength for detection was selected by preparing the individual solution of $10 \mu \mathrm{g} / \mathrm{mL}$ of Efavirenz capsule solution was scanned in the range of 200-400 $\mathrm{nm}$. The wavelength selected for the analysis $245 \mathrm{~nm}$ at which drug showed significant absorbance.

\subsubsection{Selection of stationary phase}

On the-basis of reversed phase HPLC mode, stationary phase column with $\mathrm{C} 18$ bonded phase i.e. Intersil ODS-3V $(250 \times 4.6 \mathrm{~mm})$ with particle size $5 \mu \mathrm{m}$ from Khandelwal Laboratory, Mumbai was used for separation.

\section{Optimization of mobile phase}

Different mobile phases were tried in order to find best condition for separation of Efavirenz capsule. Following composition mobile phases were tried,

Methanol: Isopropanol (75:25 V/V)

Methanol: Isopropanol (50:50 V/V)

Methanol: Isopropanol (70:30 V/V)

Methanol: Isopropanol (40:60 V/V)

Isopropanol: Methanol (90:10 V/V)

Methanol: Isopropanol (65:35 V/V)

Methanol: Isopropanol (60:40 V/V)

Methanol: Isopropanol (80:20 V/V)

\subsubsection{Mobile phase preparation}

\section{- Preparation of mobile phase}

Mobile phase was prepared by mixing methanol: Isopropanol in the ratio of $80: 20 \mathrm{v} / \mathrm{v}$.

\section{- Degassing of the mobile phase}

The prepared mobile phase was degassed by ultrasonication for $20 \mathrm{~min}$, so as to avoid the disturbances caused by dissolved gases.

\section{- Filtration of mobile phase}

The degassed mobile phase was filtered through $0.45 \mu$ filter to avoid the column clogging due to smaller particles. 
- Final chromatographic condition

System used: JASCO UV -2075

Software: Chromnav

Column used: $\quad$ C18 intersil, 4.6(i.d.) x250mm

* Mobile phase used: Methanol: Isopropanol

* Flow rate: $\quad 0.5 \mathrm{ml} / \mathrm{min}$

* UV detection: $\quad 245 \mathrm{~nm}$

* Condition: Gradient condition

\subsubsection{Sample preparation ${ }^{[14], ~[15] ~}$}

A stock solution of drug prepared by dissolving 100 mg of Efavirenz capsule in a $100 \mathrm{ml}$ volumetric flask containing $10 \mathrm{ml}$ methanol HPLC Grade to dissolve the drug , sonicated the sample for about $15 \mathrm{~min}$ and then made up to volume with mobile phase. Pipette out $10 \mathrm{ml}$ of above solution and made up to the volume to $100 \mathrm{ml}$ with mobile phase to produce $100 \mu \mathrm{g} / \mathrm{ml}$ and to Suitable dilutions were made and the sample was filtered through Nylon 6, 6 membrane $0.45 \mu \mathrm{m}$ filter. Aliquots of $20 \mu \mathrm{L}$ of the clear filtrate were injected into the HPLC column.

\section{Priming of the system}

Air in the conducting tubes was removed by manual method to obtain the continuous flow and to avoid the backpressure on the pump, avoiding the damage to the column.

\subsubsection{Conditioning of the column}

Before a new run on system, warm HPLC grade water or Mobile Phase was run at flow rate of 0.5 $\mathrm{mL} / \mathrm{min}-1$ for $1 \mathrm{hr}$, so as to remove water soluble impurities from the column. Then Mobile Phase was run at the same flow for $30 \mathrm{~min}$. conditioning of the column was done by passing methanol at $0.5 \mathrm{~mL} / \mathrm{min}$ 1 flow rate for $30 \mathrm{~min}$. So as to remove the remains of the previous run.

\subsubsection{Loading of mobile phase}

Filtered and degassed mobile phase was filled in the reservoir. Priming was in hot water every freshly ready mobile part.

\subsubsection{Baseline stabilization}

The detector was turned on for an hour before the actual run so as to obtain the stable UV light. The mobile phase run was started at required flow rate and the run was continued so as to obtain stable baseline.

\subsubsection{Loading of samples}

Properly prepared, filtered and sonicated samples were loaded into the manual injector port with the help of syringe and the sample was injected.

\subsection{Method Validation}

The planned methodology was valid as per ICH pointers. The solutions of the medicine were ready as per the sooner adopted procedure given within the experiment.

\section{A) Linearity}

To prepare six sets of the drug solution were prepared in the mobile phase containing drug at a conc. 2 to 10 $\mu \mathrm{g} / \mathrm{ml}$.each of these drug solution was injected in six concentration in one by one into column ,the peak area and retention time was determined. Mobile Phase (Methanol: Isopropanol 80:20)

$10 \mathrm{mg}$----------- stock solution of $100 \mathrm{~mL}$ (concentration $100 \mu \mathrm{g} / \mathrm{mL}$ )

1] $2 \mathrm{ml}$ from stock solution ...10 ml

2] $4 \mathrm{ml}$ from stock solution ...10 ml

3] $6 \mathrm{ml}$ from stock solution ...10 ml

4] $8 \mathrm{ml}$ from stock solution ...10 ml

$5] 10 \mathrm{ml}$ from stock solution...10 ml 


\section{B) LOD and LOQ}

The LOD and LOQ were individually determined that is predicated on calibration curve. The S.D. of y intercept of regression line may be used as S.D.

$\mathrm{LOD}=3.3 \mathrm{x} \sigma / \mathrm{s}$

$\mathrm{LOQ}=10 \mathrm{x} \sigma / \mathrm{s}$

Where, $\sigma=$ Standard deviation of $y$ intercept of regression lines

$\mathrm{S}=$ Slope of calibration curve.

\section{C) Precision}

Precision is measure of repeatability or reproducibility and it was determined by injecting 6 times the expected operating range concentration. The chromatograms were recorded to determine mean standard deviation and relative standard deviation. The intraday and intra precision was determined using $10 \mu \mathrm{g} / \mathrm{mL}$ concentration of drug. Mobile phase were used as Methanol: Isopropanol (80:20).

$10 \mathrm{mg}$----------- stock solution of $100 \mathrm{~mL}$ (concentration $100 \mu \mathrm{g} / \mathrm{mL}$ )

$1] 1.0 \mathrm{~mL}$ from stock solution $10 \mathrm{~mL}$ $(10 \mu \mathrm{g} / \mathrm{mL})$

2] $2.0 \mathrm{~mL}$ from stock solution $10 \mathrm{~mL}$ $(20 \mu \mathrm{g} / \mathrm{mL})$

3] $3.0 \mathrm{~mL}$ from stock solution $10 \mathrm{~mL}$ $(30 \mu \mathrm{g} / \mathrm{mL})$

4] $4.0 \mathrm{~mL}$ from stock solution $10 \mathrm{~mL}$ $(40 \mu \mathrm{g} / \mathrm{mL})$ $10 \mathrm{~mL}$

5] $5.0 \mathrm{~mL}$ from stock solution $(50 \mu \mathrm{g} / \mathrm{mL})$

\section{1) Intraday}

It was carried out by estimating the corresponding responses (peak area) three times on the same day between three hrs intervals. Measurement of responses (peak area) was expressed in terms of \% Relative Standard Deviation (\%RSD). Then each dilution of EFA capsule was injected and chromatogram was recorded at different intervals in the same day like $11 \mathrm{pm}, 1 \mathrm{pm}, 3 \mathrm{pm}$ and further calculation was done.

\section{2) Interday (different days)}

It was carried out by estimating the corresponding responses (peak area) of same sample were recorded on three different days. Measurement of responses (peak area) was expressed in terms of \% Relative Standard Deviation (\%RSD). Then each dilution of EFA Capsule was injected and chromatogram was recorded at different intervals in a different day like first day, second day, third day and further calculation was done.

\section{D) Accuracy}

Accuracy of projected methodology was determined on the premise of recovery study performed by normal addition technique. This involved the addition of known quantities of standard into analyzed sample .Three concentration levels were tested (50\%, 100\%, and 150\%). At each level, samples were prepared in triplicates and analyzed according to previously described procedure. Accuracy was expressed as \% recovery. Then each dilution was injected and the chromatogram of the resulting solutions was recorded and further calculation was carried out. The recovery study was performed 3 times at every level. (Mobile phase used - Methanol: Isopropanol 80:20).

1] $1 \mathrm{~mL}$ from stock solution ------------- $10 \mathrm{~mL}$ $(10 \mu \mathrm{g} / \mathrm{mL})$

2] $2 \mathrm{~mL}$ from stock solution --------------- $10 \mathrm{~mL}$ $(20 \mu \mathrm{g} / \mathrm{mL})$

3] $3 \mathrm{~mL}$ from stock solution -------------- $10 \mathrm{~mL}$ $(30 \mu \mathrm{g} / \mathrm{mL})$

\section{E) Ruggedness}

The ruggedness of Associate in nursing analytical technique is that the degree of dependableness of 
check results obtained by the analysis of identical samples beneath a spread of conditions, such as completely different laboratories, completely different analysts, different instruments, different assay temperature, totally different days, etc. Then dilution of EFA capsule was injected and the chromatograms of the resulting solutions were recorded and further calculation was carried out. (Mobile phase used - Methanol: Isopropanol $80: 20 \mathrm{v} / \mathrm{v})$.

1] $0.2 \mathrm{~mL}$ from stock solution $10 \mathrm{~mL}$ $(2 \mu \mathrm{g} / \mathrm{mL})$

2] $0.4 \mathrm{~mL}$ from stock solution $10 \mathrm{~mL}$ $(4 \mu \mathrm{g} / \mathrm{mL})$

3] $0.6 \mathrm{~mL}$ from stock solution $10 \mathrm{~mL}$ $(6 \mu \mathrm{g} / \mathrm{mL})$

4] $0.8 \mathrm{~mL}$ from stock solution $10 \mathrm{~mL}$ $(8 \mu \mathrm{g} / \mathrm{mL})$

\section{F) Robustness}

It is live of its capability to stay unaffected by tiny however deliberate modification in technique parameters and provides a sign of its dependability in traditional usage. The parameters for HPLC method include the variation in flow rate, wavelength and mobile phase composition. The Retention time and asymmetry were considered for robustness.

\section{A) Effect of flow rate variation}

Robustness of method was checked by changing flow rate from $0.5 \mathrm{~mL} / \mathrm{min}-1$ to $1.2 \mathrm{~mL} / \mathrm{min}-1$ instead of 1 $\mathrm{mL} / \mathrm{min}-1$ by injecting the three replicate injection of $(10 \mu \mathrm{g} / \mathrm{mL}$ of Efavirenz capsule at flow rate 0.5 $\mathrm{mL} / \mathrm{min}$ at $245 \mathrm{~nm}$ ).

\section{B) Effect of wavelength variation}

Robustness of method was checked by using wavelength $240 \mathrm{~nm}$ and $245 \mathrm{~nm}$ instead of $250 \mathrm{~nm}$ by injecting the three replicate injections of $(10 \mu \mathrm{g} / \mathrm{mL}$ of Efavirenz capsule at flow rate $0.5 \mathrm{~mL} / \mathrm{min}$ at $245 \mathrm{~nm}$ ).

\section{C) Effect of mobile phase composition variation}

Robustness of method was checked by using mobile phase composition 65:35and 60:40 instead of $55: 45$ by injecting the three replicate injection of standard $(10 \mu \mathrm{g} / \mathrm{mL}$ of Efavirenz capsule at flow rate 0.5 $\mathrm{mL} / \mathrm{min}$ at $245 \mathrm{~nm}$ ).

\section{V. RESULT AND DISCUSSION}

\subsection{Organoleptic characteristics}

Colour : White colour

Odour : Odorless

Taste: Tasteless

\subsection{Physical Parameters}

\subsubsection{Melting point determination}

Reported M.P: $139-141^{\circ} \mathrm{C}$

Observed M.P: $140-142{ }^{\circ} \mathrm{C}$

\subsubsection{Solubility of drugs in different solvents}

Solubility of Efavirenz capsule was observed by dissolving them in different solvents as below, as show in Table No. 4.

Table 4. Solubility study

\begin{tabular}{|c|c|c|}
\hline Sr.No. & Solvent & Solubility \\
\hline 1 & Water & Insoluble \\
\hline 2 & Methanol & Soluble \\
\hline 3 & Sodium hydroxide & Freely soluble \\
\hline 4 & Ethanol & Soluble \\
\hline 5 & Isopropanol & Freely soluble \\
\hline
\end{tabular}

\subsection{IR studies}

Identification of Efavirenz capsule is confirmed by IR Spectra. All peaks were found in Efavirenz capsule drug. As shown in Figure No.1. 


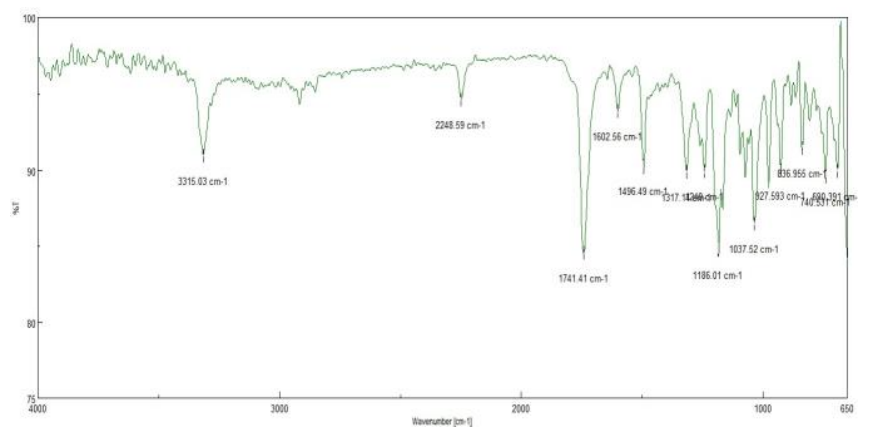

Figure 1. IR Spectra for Efavirenz capsule drug

Table 5. Interpretation of IR spectrum Efavirenz

\begin{tabular}{|c|c|}
\hline \multicolumn{2}{|c|}{ capsule } \\
\hline Functional Group & $\begin{array}{l}\text { Wave number (cm-1) } \\
\text { (IR Range) }\end{array}$ \\
\hline N-H stretching & $3313.15 \mathrm{~cm}-1$ \\
\hline $\mathrm{C}=\mathrm{O}$ stretching & $1741.7 \mathrm{~cm}-1$ \\
\hline CH stretching & $2248.59 \mathrm{~cm}-1$ \\
\hline C-F bending & $1496.59 \mathrm{~cm}-1$ \\
\hline C-CL bending & $827.538 \mathrm{~cm}-1$ \\
\hline
\end{tabular}

\subsection{Ultra-visible spectroscopy}

\subsubsection{Detection of analytical wavelength}

The standard solution of EFA capsule was scanned in the range of 200-450 nm and the $\lambda$ Max of Efavirenz capsule was found to be $245 \mathrm{~nm}$ against methanol, as shown in Figure No.2.

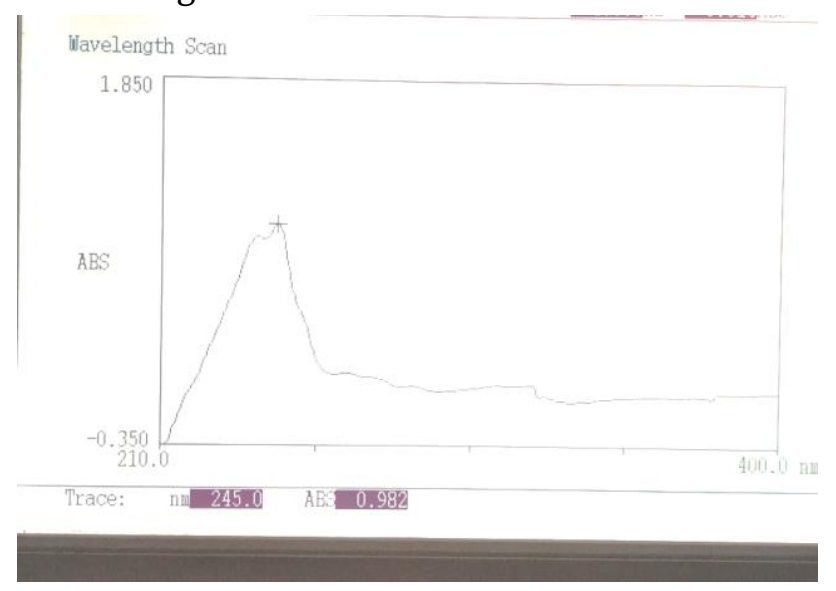

Figure 2. Detection of analytical wavelength
Calibration Curve- Absorbance values for calibration curve of Efavirenz capsule at $\mathbf{2 4 5} \mathbf{n m}$.

Table 6. Concentration VS Absorbance

\begin{tabular}{|c|c|}
\hline $\begin{array}{c}\text { Concentration } \\
(\mu \mathrm{g} / \mathrm{ml} .)\end{array}$ & $\begin{array}{c}\text { Absorbance } \\
(\mathrm{nm} .)\end{array}$ \\
\hline 0 & 0 \\
\hline 0.2 & 0.21 \\
\hline 0.4 & 0.42 \\
\hline 0.6 & 0.65 \\
\hline 0.8 & 0.82 \\
\hline 1 & 0.99 \\
\hline
\end{tabular}

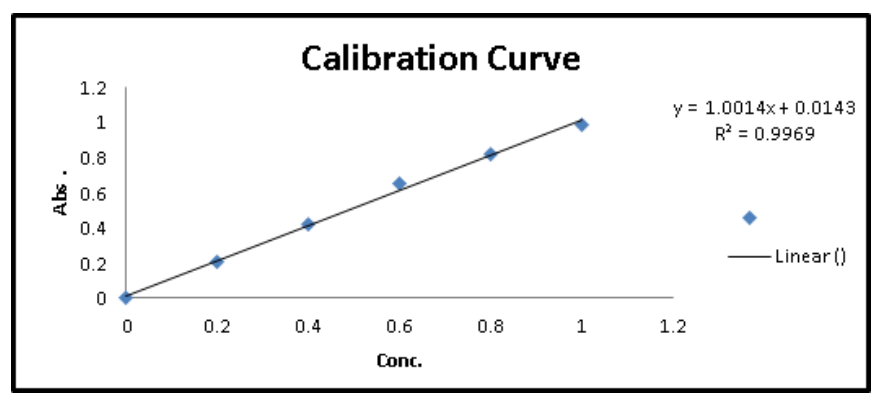

Figure 3. Calibration curve of Efavirenz capsule

Table 7. Regression data for calibration curve of Efavirenz capsule

\begin{tabular}{|c|c|c|}
\hline Sr. No. & Parameter & Efavirenz Capsule \\
\hline 1 & Slope & 1.001 \\
\hline 2 & Intercept & 0.014 \\
\hline 3 & $\begin{array}{c}\text { Regression } \\
\text { Coefficient }\end{array}$ & 0.996 \\
\hline 4 & Range & $2-12 \mu \mathrm{g} / \mathrm{ml}$ \\
\hline
\end{tabular}

\subsection{UV method validation}

\section{A) Linearity}

Linearity study was carried out using serial dilution of stock solution; dilution was taken $2-10 \mu \mathrm{g} / \mathrm{ml}$. And linearity curve was plotted against concentration vs. absorbance, as shown in Table No.8 and linearity curve of Efavirenz capsule shown in Figure No. 4. 
Table 8. Linearity of Efavirenz capsule

\begin{tabular}{|c|c|}
\hline $\begin{array}{c}\text { Concentration } \\
(\mu \mathrm{g} / \mathrm{ml} .)\end{array}$ & Absorbance (nm.) \\
\hline 0 & 0 \\
\hline 2 & 0.09 \\
\hline 4 & 0.16 \\
\hline 6 & 0.24 \\
\hline 8 & 0.35 \\
\hline 10 & 0.39 \\
\hline
\end{tabular}

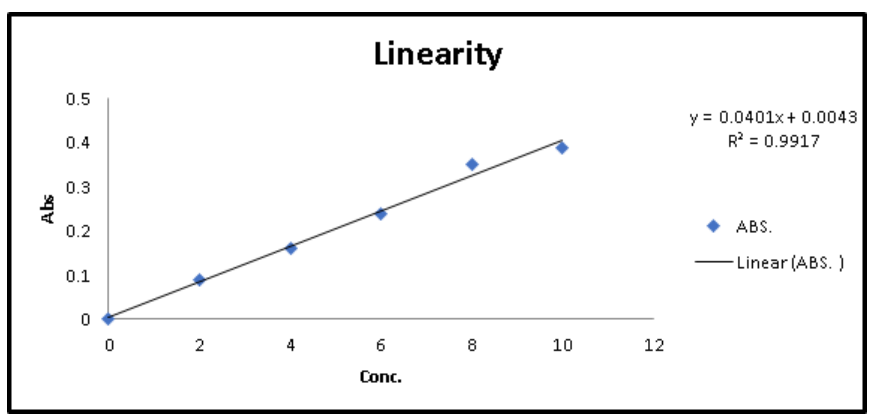

Figure 4. Linearity curve of Efavirenz capsule

Table 9. regression data for linearity curve Efavirenz capsule

\begin{tabular}{|c|c|c|}
\hline Sr.No. & Parameter & $\begin{array}{c}\text { Efavirenz } \\
\text { Capsule }\end{array}$ \\
\hline 1 & Slope & 0.040 \\
\hline 2 & Intercept & 0.004 \\
\hline 3 & $\begin{array}{c}\text { Regression } \\
\text { Coefficient }\end{array}$ & 0.991 \\
\hline 4 & Range & $2-10 \mu \mathrm{g} / \mathrm{ml}$ \\
\hline
\end{tabular}

The calibration plot Efavirenz capsule follow BeerLambert's law at selected wavelength indicates response is linear function of concentration in the range of $2-10 \mathrm{ug} / \mathrm{mL}$ in $\mathrm{UV}$ spectrophotometric method.

\section{B) LOD and LOQ}

The LOD and LOQ were one by one determined that is predicated on calibration curve. The S.D. of $y$ intercept of regression line may be used as S.D.
$\mathrm{LOD}=3.3 \times \sigma / \mathrm{s}$

LOQ-10x $\sigma / \mathrm{s}$

Where, $\sigma=$ Standard deviation of $y$ intercept of regression lines,

$\mathrm{S}=$ Slope of calibration curve

LOD was found to be $0.37 \mu \mathrm{g} / \mathrm{ml}$

LOQ was found to be $1.15 \mu \mathrm{g} / \mathrm{ml}$ which indicates adequate sensitivity method.

\section{C) Accuracy}

Accuracy of an analytical method is the closeness of test results obtained, by the method to the true, value. It was checked the accuracy of proposed method, was carried out 80,100,120 \% of Efavirenz drug concentration as per ICH guidelines. Accuracy was found to be $97.46-100.23 \%$. As shown in Table No. 10.

Table 10. Accuracy of Efavirenz capsule

\begin{tabular}{|c|c|c|c|}
\hline $\begin{array}{c}\text { Efavirenz } \\
\text { capsule }\end{array}$ & $\begin{array}{c}\text { Recovery } \\
\text { Mean* }\end{array}$ & \pm S.D. & \%R.S.D. \\
\hline $80 \%$ & 100.23 & 1.4 & 1.39 \\
\hline $100 \%$ & 97.46 & 2.49 & 2.55 \\
\hline $120 \%$ & 98.44 & 1.74 & 1.76 \\
\hline
\end{tabular}

* Indicates three replicate

\section{D) Precision}

The intraday and inter day's precision study of Efavirenz capsule was carried out by estimating the corresponding responses three times on the same day and on three different days and expressed as \% RSD. The low values of \% R.S.D. (<2\%) for intra and inter day's variation, which suggested an excellent precision of method. As shown in Table No.11. 
Table11. Precision

\begin{tabular}{|c|c|c|c|c|}
\hline Drug & \multicolumn{2}{|c|}{$\begin{array}{c}\text { Intra-day } \\
\text { Precision ( } \mathrm{N}=3 \text { ) }\end{array}$} & \multicolumn{2}{|c|}{$\begin{array}{c}\text { Inter-day } \\
\text { Precision( } N=3)\end{array}$} \\
\hline \multirow[t]{2}{*}{$\begin{array}{c}\text { EFA } \\
\text { capsule }\end{array}$} & $\begin{array}{r} \pm \text { S.D. } \\
\text { R }\end{array}$ & $\%$ & \pm S.D. & $\%$ \\
\hline & $\begin{array}{l}0.005 \\
0.606\end{array}$ & & $\begin{array}{l}0.007 \\
0.791\end{array}$ & \\
\hline
\end{tabular}

\section{E) Ruggedness}

The ruggedness of associate degree analytical methodology is that the degree of reliability of take a look at results obtained by the analysis of a similar samples below a range of conditions, such as differ laboratories, totally different analysts, totally different instruments, totally different countless reagents, totally different advance assay times, completely different assay temperature, completely different days, etc. By using this dilution the absorbance was taken and the further calculation was carried out. As shown in Table No.12.

Table 12. Ruggedness Efavirenz capsule

\begin{tabular}{|c|c|c|}
\hline Efavirenz capsule & \pm S.D. & \%R.S.D \\
\hline Analyst 1 & 0.0083 & 0.84 \\
\hline Analyst 2 & 0.01 & 0.98 \\
\hline
\end{tabular}

\section{F) Robustness}

Low values of SD and \% RSD obtained after introducing small deliberate changes in the developed UV method indicated the robustness of method. As shown in Table No.13.
Table 13. Robustness

\begin{tabular}{|c|c|c|}
\hline Drug & \pm S.D. & \%R.S.D. \\
\hline Efavirenz capsule & 0.01 & 0.8264 \\
\hline
\end{tabular}

\subsection{HPLC analysis}

\subsubsection{Selection of analytical wavelength}

$245 \mathrm{~nm}$ was selected for analysis of Efavirenz in their capsule dosage forms, at which the show significant absorbance.

5.6.2 Optimization of mobile phase for HPLC method development

Optimized method -Methanol: Isopropanol (80:20) Flow Rate: $0.5 \mathrm{ml} / \mathrm{min}$

Wavelength: $245 \mathrm{~nm}$

Retention time: 3.35

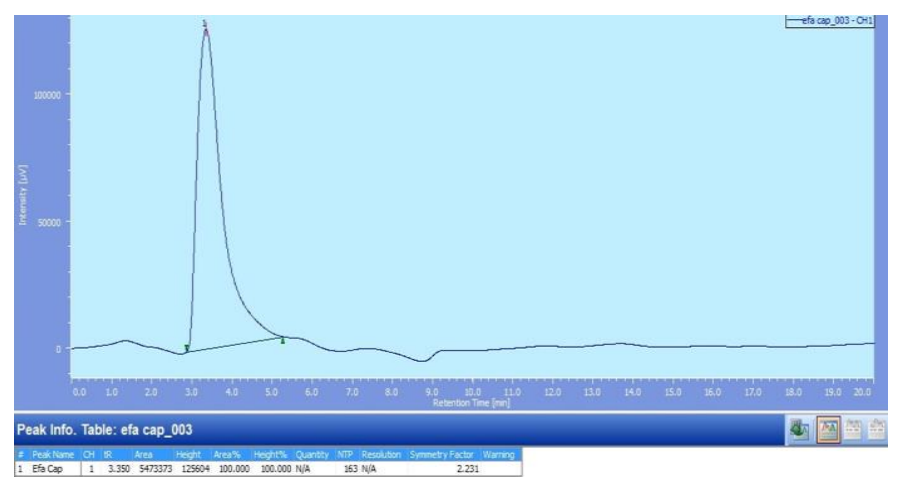

Figure 5. Optimization of chromatogram

Inference - Peak area is observed 5471373 and Retention time is observed 3.350, lowest peak area and lowest retention time hence Mobile Phase proportion was accepted.

\subsubsection{High performance liquid chromatography}

\subsubsection{Method validation}

\section{A) Linearity and range}

The calibration plot Efavirenz capsule follow BeerLambert's law, the correlation coefficient, intercept 
and slope were found respectively. The good correlation coefficient indicates the method is linear over the concentration range. As shown in Table No. 14 .

Table 14. linearity concentration vs. area

\begin{tabular}{|c|c|}
\hline Conc. & Area \\
\hline 2 & 645044 \\
\hline 4 & 2069238 \\
\hline 6 & 4401572 \\
\hline 8 & 5387951 \\
\hline 10 & 6898516 \\
\hline
\end{tabular}

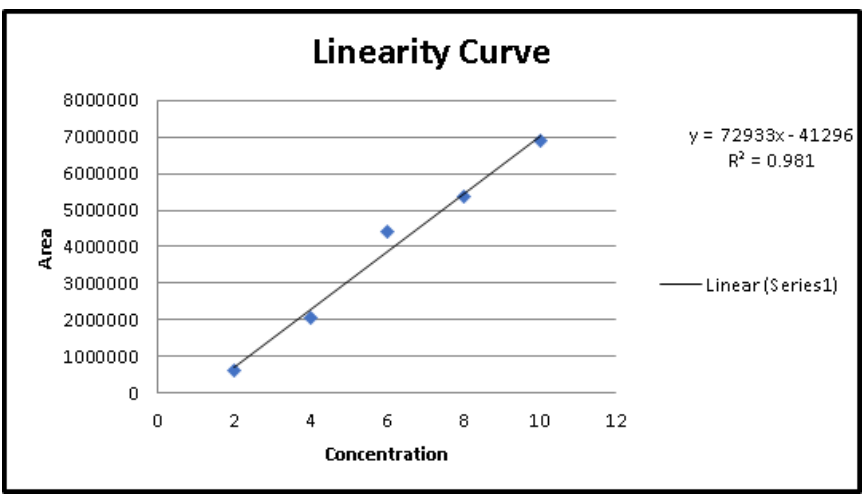

Figure 6. linearity curve of Efavirenz capsule

Table 15. Linear regression data

\begin{tabular}{|c|c|c|}
\hline Sr.No. & Parameter & Efavirenz \\
& & Drug \\
\hline 1 & Slope & 72933 \\
\hline 2 & Intercept & 41296 \\
\hline 3 & $\begin{array}{c}\text { Regression } \\
\text { Coefficient }\end{array}$ & 0.981 \\
\hline 4 & Range & $2-10 \mu \mathrm{g} / \mathrm{ml}$ \\
\hline
\end{tabular}

\section{B) LOD AND LOQ}

The LOD and LOQ were individually determined that is predicated on calibration curve. The S.D. of y intercept of regression line may be used as S.D.

$\mathrm{LOD}=3.3 \mathrm{x} \sigma / \mathrm{s}$

$\mathrm{LOQ}=10 \mathrm{x} \sigma / \mathrm{s}$
Where, $\sigma=$ Standard deviation of y intercept of regression lines,

$\mathrm{S}=$ Slope of calibration curve

LOD was found to be $=1.86 \mu \mathrm{g} / \mathrm{ml}$

LOQ was found to be $=5.60 \mu \mathrm{g} / \mathrm{ml}$

\section{C) Precision}

Intraday and Interday precision is carried out in same day on different day as expressed as \% R.S.D. The low values of \% R.S.D. for intra and inter day's variation, which suggested an excellent precision of method. As shown in Table No. 16.

Table 16 Precision

\begin{tabular}{|l|l|l|}
\hline \multirow{4}{*}{$\begin{array}{l}\text { Efavirenz } \\
\text { Capsule }\end{array}$} & $\begin{array}{l}\text { Intra-day } \\
\text { Precision } \\
(\mathrm{N}=3)\end{array}$ & $\begin{array}{l}\text { Inter-day } \\
(\mathrm{N}=3)\end{array}$ \\
\cline { 2 - 3 } & $\begin{array}{l} \pm \text { S.D. } \\
\text { \% R.S.D. }\end{array}$ & \\
\cline { 2 - 3 } & 0.041 & 0.0008 \\
& 2.59 & \\
\hline
\end{tabular}

\section{D) Accuracy}

Accuracy of an analytical method is the closeness of test results obtained by the method to the true value. It was ascertained on the basis of recovery studies performed by standard addition method at 80, 100 and $150 \%$ level, known amount of standard drugs were added to analyzed sample and subjected them to the proposed method for HPLC Results from recovery studies were within acceptable limit 100.42$102.33 \%$ for Efavirenz capsule respectively indicating accuracy of method was good. As shown in Table No. 17.

Table 17. Accuracy

\begin{tabular}{|c|c|c|}
\hline \% Level & Recovery Mean* & $\begin{array}{c} \pm \text { S.D. of } \\
\text { response }\end{array}$ \\
\hline $80 \%$ & 100.43 & 25.84 \\
\hline $100 \%$ & 102.33 & 431779.9 \\
\hline $150 \%$ & 100.42 & 42.43 \\
\hline
\end{tabular}

*indicates three replicates 


\section{E) Robustness study}

Robustness study is carried out by small deliberate changes like change in flow rate, change in wavelength, and change in mobile phase composition .It determines mean and S.D. value. As shown in Table No.18, 19, 20 respectively.

\section{a) Change In Flow Rate}

Table 18. Change in Flow Rate

\begin{tabular}{|c|c|}
\hline Flow Rate & Retention time \\
\hline $0.1 \mathrm{ml} / \mathrm{min}$ & 6.375 \\
\hline $0.5 \mathrm{ml} / \mathrm{min}$ & 6.325 \\
\hline $1 \mathrm{ml} / \mathrm{min}$ & 6.375 \\
\hline Mean SD $(\mathrm{N}=3)$ & $6.358 \pm 0.02$ \\
\hline
\end{tabular}

b) Change In Wavelength

Table 19. Change in Wavelength

\begin{tabular}{|c|c|}
\hline Wavelength & Retention time \\
\hline $240 \mathrm{~nm}$ & 3.292 \\
\hline $245 \mathrm{~nm}$ & 6.242 \\
\hline $250 \mathrm{~nm}$ & 6.492 \\
\hline Mean SD (N=3) & $5.342 \pm 1.77$ \\
\hline
\end{tabular}

c) Mobile phase composition

Table 20. Mobile phase composition

\begin{tabular}{|c|c|}
\hline Mobile Phase & Retention time \\
\hline Methanol :Isopropanol (65:35) & 6.192 \\
\hline Methanol :Isopropanol (60:40) & 6.317 \\
\hline Methanol :Isopropanol (55:45) & 6.317 \\
\hline Mean SD (N=3) & $6.275 \pm 0.072$ \\
\hline
\end{tabular}

\section{DISCUSSION}

The present research work attempted to prepare an economical and stable. An analysis of Efavirenz drug in their dosage forms by using UV spectroscopy the drug shows maximum wavelength $245 \mathrm{~nm}$ against methanol also HPLC respectively. The proposed method obey 'Beers-Lamberts' law having $2 \mu \mathrm{g} / \mathrm{ml}$ $10 \mu \mathrm{g} / \mathrm{ml}$ Concentration. Slope 1.001, Intercept 0.014 and Regression Coefficient 0.996 was found also to perform UV Spectroscopy method validation parameter like linearity (Regression coefficient $0.991)$, LOD and LOQ $(0.37 \mu \mathrm{g} / \mathrm{ml})$,accuracy is found to be 97.46 to $100.23 \%$, precision ( Intraday precision \pm S.D.0.005, \% R.S.D. 0.606 and interday precision ${ }_{ \pm}$S.D.0.07,\%R.S.D. 0.791), Ruggedness (Analyst1 $: \pm$ S.D.0.0083,\%R.S.D.0.84 and Analyst 2 : \pm S.D.0.01,\%R.S.D.0.98).

The research work to attempts HPLC pumps washing and column washing. It was used column C18. During optimization of mobile phase number of trial mobile phase carried out Methanol: Isopropanol (75:25 V/V), Methanol: Isopropanol (50:50 V/V ), Methanol: Isopropanol (70:30V/V), Methanol: Isopropanol (40:60 V/V), Isopropanol: Methanol (90:10 V/V), Methanol: Isopropanol (65:35 V/V), Methanol: Isopropanol (60:40 V/V) and optimization of mobile phase is Methanol: Isopropanol $(80: 20 \mathrm{~V} / \mathrm{V})$ having flow rate $0.5 \mathrm{ml} / \mathrm{min}$, wavelength $245 \mathrm{~nm}$ and column used for C18. Retention time was found 3.35 and sharp peak observed. Method validation is carried out by using linearity (Regression coefficient $0.981))$, LOD and LOQ $(1.86 \mu \mathrm{g} / \mathrm{ml}$ and $5.60 \mu \mathrm{g} / \mathrm{ml}$ respectively), precision (Intraday precision ${ }_{ \pm S}$ S.D.0.041, \%R.S.D. 2.59 and interday precision \pm S.D.0.0008, \% R.S.D.6.8), accuracy found to be 100.42 to 100.43), robustness [(change in flow rate, change in wavelength, mobile phase composition) (mean \pm S.D.6.358 $\pm 0.02, \quad 5.342 \pm 1.77, \quad 6.275 \pm 0.072$ respectively). 


\section{ACKNOWLEDGEMENT}

The authors are thankful to the Cipla Ltd, Goa, for providing the gift samples of Efavirenz and also thanks for Shubham Devakr for providing Efavirenz Capsule. We are highly thankful of teaching staff of Rajarambapu College of pharmacy, kasegaon.For providing necessary information required for research work. Also we are highly acknowledged the help and guidance of Miss. A.R.Dhole and Dr.V.R.Salunkhe. Also thanks of friends Nikita, Sanmati, Rajeshwar for help me during this research work.

\section{REFERENCES}

[1]. P. Sharma, A. Chawla, S. Arora, and P. Pawar, Novel drug delivery approaches on antiviral and antiretroviral agents, "Journal of Advanced Pharmaceutical Technolology and Research", 3(3), 2012; 147-159.

[2]. The American Society of Health-System Pharmacists, from the original on 17 November 2016. Retrieved 28 November 2016.

[3]. A. Mayure, V. Kumar, A. Mayure, and C. P. Meher, a current review on antiviral drugs.

[4]. M.A. Potdar, Pharmaceutical Quality Assurance, 2nd edn, Nirali prakashan, 5.7-8.4.

[5]. D. A. Skoog, F. J. Holler and T.A. Nieman, "Principles of instrumental analysis", saunders college publishing harcourt brace college publishers (5); 2005, 725- 750.

[6]. G. R. Chatwal, "Instrumental methods of chemical analysis", himalaya publishing house pvt. Ltd, 2011, 2.624-2.639.

[7]. ICH Topic Q 2 (R1) Validation of Analytical Procedures, Text and Methodology June 1995.

[8]. F. A. Mehta, "Simultaneous estimation of ambroxol hydrochloride and doxofylline in pharmaceutical formulation by HPTLC-desitometric method", Journal of Chromat Separation Techniq. 4; 2013, 168

[9]. R. S. Phani., K. Prasad and U. Reddy, "Scientific approach for RPHPLC method development complete review", International Journal of Science Innovations and Discoveries, 2 (6); 2012, 218-228.

[10]. D. Jain, S. Jain, A. Maulik, Estimation of metformin hydrochloride, pioglitazone hydrochloride and glimepiride by RP-HPLC in tablet formulation, J Chromatogrphy Sci,2008; 46(6) :501-504.

[11]. R. S. Phani., K.R.S. Prasad and U. Reddy, "Scientific approach for RP-HPLC method development complete review", International Journal of Science Innovations and Discoveries, 2 (6), 2016, 218-228.

[12]. M. B. Reddy, C. Reddy and G. V. S. Gillella, "UV spectrophotometric method for estimation of efavirenz in bulk and dosage form", Asian Journal of Pharmaceutical Analysis and Medicinal Chemistry, 4(2); 2006, 112-130.

[13]. Y.D. Dange, S. M. Honmane, S. D. Bhinge, V. R. Salunkhe, D.R. Jadge "Development and Validation of UV-Spectrophotometric Method for Estimation of Metformin in Bulk and Tablet Dosage", Indian Journal of Pharmaceutical Education and Research, 51(45); 2017, 754-759.

[14]. A. K. Manikanta, B. S. Naga, M. Nasare, V.V.L.N. Prasad, P. V. Diwan, "Development and validation of UV spectrophotometric method for simultaneous estimation of lamivudine and efavirenz in the pharmaceutical dosage form", journal .adv. pharm .edu. and res., 2 (4); 2012, 210-214.

[15]. R. Nathi , S.S. Rao, S. Sahoo, N. Sunkara , V.R.M. Gupta, "Stability indicating RP-HPLC method development and validation of efavirenz in bulk and pharmaceutical dosage form”, International Journal of Pharmacy and Biological Sciences, 7 (2); 2017, 223-229.

\section{Cite this article as :}

Punam S. Desai, Archana R. Dhole, Rajeshwar V. Chavan, "Development and Validation of High-Performance Liquid Chromatography Method for Analysis of Efavirenz In Capsule Dosage Form ", International Journal of Scientific Research in Science and Technology (IJSRST), Online ISSN : 2395-602X, Print ISSN : 2395-6011, Volume 6 Issue 5, pp. 307-322, September-October 2019. Available at doi : https://doi.org/10.32628/IJSRST19662 Journal URL : http://ijsrst.com/IJSRST19662 